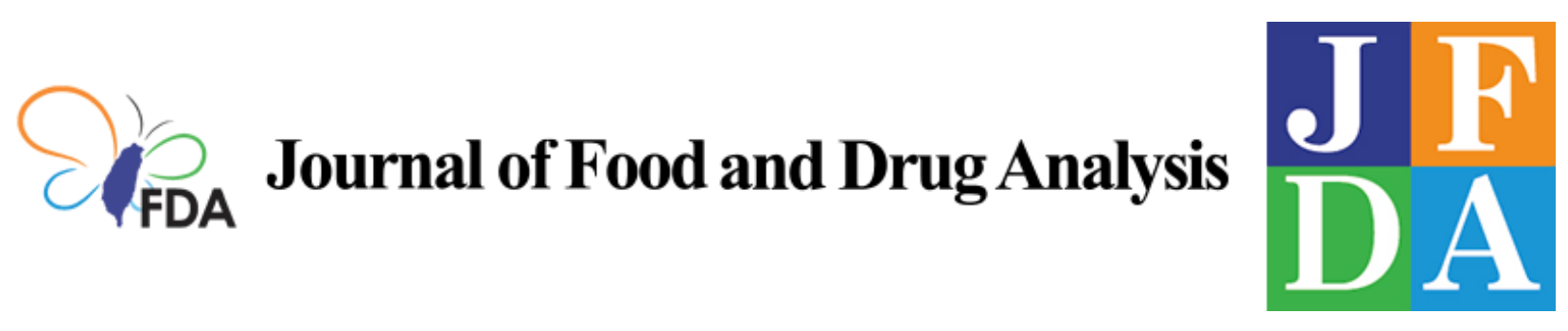

Volume 28 | Issue 2

Article 10

2020

\title{
A multi-analyte LC-MS/MS method for screening and quantification of nitrosamines in sartans
}

Follow this and additional works at: https://www.jfda-online.com/journal

Part of the Food Science Commons, Medicinal Chemistry and Pharmaceutics Commons, Pharmacology Commons, and the Toxicology Commons

(c) (1) (9)

This work is licensed under a Creative Commons Attribution-Noncommercial-No Derivative Works 4.0 License.

\section{Recommended Citation}

Chang, Shu-Han; Chang, Ching-Chia; Wang, Li-Jing; Chen, Wei-Ching; Fan, Shu-Yu; Zang, Chi-Zong; Hsu, YaHui; Lin, Mei-Chih; Tseng, Su-Hsiang; and Wang, Der-Yuan (2020) "A multi-analyte LC-MS/MS method for screening and quantification of nitrosamines in sartans," Journal of Food and Drug Analysis: Vol. 28 : Iss. 2 , Article 10.

Available at: https://doi.org/10.38212/2224-6614.1063

This Original Article is brought to you for free and open access by Journal of Food and Drug Analysis. It has been accepted for inclusion in Journal of Food and Drug Analysis by an authorized editor of Journal of Food and Drug Analysis. 


\title{
A multi-analyte LC-MS/MS method for screening and quantification of nitrosamines in sartans
}

\author{
Shu-Han Chang, Ching-Chia Chang, Li-Jing Wang, Wei-Ching Chen, Shu-Yu Fan, \\ Chi-Zong Zang*, Ya-Hui Hsu, Mei-Chih Lin, Su-Hsiang Tseng, Der-Yuan Wang
}

Food and Drug Administration, Ministry of Health and Welfare, Executive Yuan, 161-2 Kunyang St., Nangang Dist., Taipei 11561, Taiwan

\begin{abstract}
An incident of sartan medicine contamination was notified by Europe in June 2018. The contaminant was identified as a probable carcinogenic nitrosamine and the recalls of sartan medicines were soon made. Since then, more nitrosamine contaminants in sartan medicines were reported. To broaden the applicability and variety in nitrosamine determination, a multi-analyte method is required. In this study, a feasible and sensitive multi-analyte LC-MS/MS method for determination of 12 nitrosamines in sartans was established, where the active pharmaceutical ingredients and final products merchandised in Taiwan were also examined. Chromatographic separation was achieved on an Xselect ${ }^{\circledR}$ HSS T3 column $(15 \mathrm{~cm} \times 3 \mathrm{~mm}$ i.d., $3.5 \mu \mathrm{m})$ with gradient elution using mobile phase A consisting of $0.1 \%$ formic acid in water and mobile phase B consisting of $0.1 \%$ formic acid in acetonitrile/methanol (2:8). Validation of the proposed method was also carried out. The limit of detection and limit of quantification for 12 nitrosamines were $20 \mathrm{ng} / \mathrm{g}$ and $50 \mathrm{ng} / \mathrm{g}$, respectively. The intra-day and inter-day recoveries of nitrosamines were among $80-120 \%$ with precision of $20 \%$ for most nitrosamines within sartans matrices. The method was successfully established and applied to authentic samples which a total of 98 positive samples containing 5 distinct nitrosamines, including $N$-nitrosodiethylamine, $N$-nitrosodimethylamine, $N$-nitroso- $N$-methyl-4-aminobutyric acid, $N$-nitrosomorpholine and $N$ nitrosopiperidine, were detected from 557 authentic samples.
\end{abstract}

Keywords: Carcinogens, Liquid chromatography, Mass spectrometry, Nitrosamines, Sartans

\section{Introduction}

A ngiotensin II is a biologically active component that plays an important role in the regulation of blood pressure, secretion of aldosterone, and homeostasis of fluid in human body. Besides, it is an etiological factor for cardiovascular diseases [1]. Angiotensin II receptor blockers (ARBs), also known as angiotensin II receptor type 1 antagonists or "sartans", have been widely applied for treating cardiovascular diseases such as hypertension, heart failure, myocardial infarction, and diabetic nephropathy [1-3]. To date, several sartans, such as losartan and valsartan, have been launched by many countries [4].
These agents have been manufactured for years where impurities and related substances are found as analogs or degraded fragments of sartans [5-8]. Recently, unexpected carcinogenic impurities were detected in sartan medicines. Those compounds were further identified as nitrosamine analogs $\mathrm{N}$ nitrosodiethylamine (NDEA) and $N$-nitrosodimethylamine (NDMA). Those nitrosamine impurities are produced as by-products resulted from the alteration of the manufacturing processes $[9,10]$. Generally, nitrosamines are found in natural environment and industrial manufacturing, such as pesticides, rubbers, dyes, and pharmaceuticals $[11,12]$. In industry, nitrosamines are inferred to forming in manufacturing processes that employ

Received 9 September 2019; accepted 19 December 2019.

Available online 27 June 2020

* Corresponding author at: Fax: +886 26531764 .

E-mail address: heavenincry@fda.gov.tw (C.-Z. Zang). 
amines, nitrates, and nitrites under a wide range of $\mathrm{pH}$ levels, via different mechanisms such as nitrosation by nitrite $[13,14]$. Oxidation of unsymmetrical dimethylhydrazine (UDMH) also affords nitrosamines [15]. For sartans, the application of alternative solvents in sartan production led to the production of nitrosamines, for example, NDMA was generated from dimethylformamide (DMF) and NDEA was generated from triethylamine (TEA) [16]. Nitrosamines are considered as potential human carcinogens and the cancer risk has been estimated which the excess lifetime is $10^{-5}$ to $10^{-6}$ in the concentration range $0.7-100 \mathrm{ng} / \mathrm{L}$ (drinking water) [17-19]. The risk of nitrosamines for human health has been highly dressed that many governments impose strict regulations on nitrosamines. For example, NDEA and NDMA are categorized as Group 2A substances (probably carcinogenic to humans) by International Agency for Research on Cancer (IARC) of WHO, category $1 \mathrm{~B}$ by the European Union (Presumed to have carcinogenic potential for humans), and category B2 (probable human carcinogen) by U.S.; besides, $\mathrm{N}$-nitrosodipropylamine (NDPA), N-nitrosomethylethylamine (NMEA), $N$-nitrosomorpholine (NMOR), $N$-nitrosopiperidine (NPIP) and $N$ nitrosopyrrolidine (NPYR) are categorized as B2 level by IARC [19]. As a consequence, U.S. EPA (Environmental Protection Agency) incorporates 6 nitrosamines in the regulation, including $\mathrm{N}$-nitrosodibutylamine (NDBA), NDEA, NDMA, NDPA, NMEA and NPYR [20]. Due to the probable hazard to human body, limits of nitrosamines in sartans were regulated that U.S. FDA drew up an interim limit which the acceptable intakes for NDEA, NDMA and NMBA in 8 sartans are 26.5, 96 and $96 \mathrm{ng} /$ day, respectively [21].

The recent incident of nitrosamine contamination in sartan medicines has raised concerns regarding the medication safety in many countries. Inevitably, Taiwan was also affected that active pharmaceutical ingredients (APIs) and final products of 5 sartans (candesartan cilexetil, irbesartan, losartan, olmesartan cilexetil and valsartan), and final products of 2 sartans (azilsartan and telmisartan) were imported. It's required to develop an analytical method for screening nitrosamines in pharmaceuticals. In many studies, it focused on the detection of nitrosamines in water matrices [12,18,22,23]. For example, Ripollés et al. developed a sensitive method for determination of 8 nitrosamines in water which demonstrated a good performance of determination at a low concentration level [22]. Only few works focused on screening nitrosamines in pharmaceutical matrices. Parr and Joseph have reviewed the determination method of nitrosamines including GC-based, LC-based and non-chromatographic methods [24]. Among those methods, LCMS/MS has various advantages in analysis including less amount of sample usage, thermal applicability of analytes and lower detection limit for determination of nitrosamines in pharmaceuticals $[25,26]$. Therefore, this study aimed at establishing a feasible and sensitive method for screening of 12 nitrosamines in sartans using LC-MS/MS, whereas method validation was carried out. The proposed method was further applied for the analysis of sartan APIs and final products merchandised in Taiwan.

\section{Materials and methods}

\subsection{Chemicals and reagents}

$\mathrm{N}$-nitrosodiethylamine (NDEA), $\mathrm{N}$-nitrosodimethylamine (NDMA), $N$-nitrosodipropylamine (NDPA), $\mathrm{N}$ nitrosodimethylamine- $\mathrm{d}_{6}\left(\mathrm{NDMA}-\mathrm{d}_{6}\right)$ and $N$-nitrosodipropylamine- $\mathrm{d}_{14}\left(\mathrm{NDPA}-\mathrm{d}_{14}\right)$ were purchased from AccuStandard (CT, USA). N-nitrosoethylisopropylamine (NEIPA) was purchased from BOC Sciences (NY, USA). N-nitrosodiisopropylamine (NDiPA) was purchased from Chem Service (PA, USA). $\mathrm{N}$-nitrosodiethanolamine (NDELA), $\mathrm{N}$-nitrosomorpholine (NMOR) and $N$-nitrosopyrrolidine (NPYR) were purchased from Sigma-Aldrich (MO, USA). $N$-nitrosopiperidine (NPIP) was purchased from Supelco (PA, USA). N-nitrosodiisopropanolamine (NDiPLA), $\mathrm{N}$-nitroso- $\mathrm{N}$-methyl-4-aminobutyric acid (NMBA), $N$-nitrosomethylethylamine (NMEA), $\mathrm{N}$-nitrosodiethylamine- $\mathrm{d}_{4} \quad\left(\mathrm{NDEA}-\mathrm{d}_{4}\right), \quad \mathrm{N}$-nitrosodiethanolamine- $\mathrm{d}_{8}\left(\mathrm{NDELA}-\mathrm{d}_{8}\right)$, and $N$-nitroso- $N$ methyl-4-aminobutyric acid- $\mathrm{d}_{3}\left(\mathrm{NMBA}-\mathrm{d}_{3}\right)$ were purchased from TRC (ON, Canada). The chemical structures of 12 nitrosamines are shown in Fig. 1. 557 samples from 5 sartans, including candesartan cilexetil (4 APIs and 6 final products), irbesartan (35 APIs and 28 final products), losartan (68 APIs and 198 final products), olmesartan cilexetil (8 APIs and 18 final products), and valsartan (65 APIs and 127 final products), were collected and submitted by local public health bureaus of Taiwan. The chemical structures of 5 sartans are shown in Fig. 2. Methanol and formic acid of LC-MS grade were purchased from Sigma-Aldrich (MO, USA). Acetonitrile of LC-MS grade was purchased from J.T Baker (NJ, USA). Water 
of LC-MS grade was purchased from Scharlau (Barcelona, Spain).

\subsection{Instrumentation and chromatographic conditions}

The experiments were performed on a Waters Acquity UPLC $^{\circledR}$ (Waters Assoc., Milford, MA, USA) coupled to a 6500 triple quadrupole linear ion trap mass spectrometer (MS) equipped with an atmospheric-pressure chemical ionization (APCI) source (AB Sciex, USA), and operated in multiple reaction monitoring (MRM) mode. The MRM parameters including MRM transitions, quantifier, qualifier, collision energy and declustering potential are provided in Table 1 . The chromatographic separation was carried out on a trifunctional alkyl C18 bonded phase column Xselect ${ }^{\mathbb{B}}$ HSS T3 column $(15 \mathrm{~cm} \times 3 \mathrm{~mm}$ i.d., $3.5 \mu \mathrm{m})$ (Waters Assoc., Milford, MA, USA) at $40{ }^{\circ} \mathrm{C}$ with a constant flow rate of $0.6 \mathrm{~mL} / \mathrm{min}$ using gradient elution of mobile phase A consisting of $0.1 \%$ formic acid in water and mobile phase B consisting of $0.1 \%$ formic acid in acetonitrile/methanol (2:8). Each sample was analyzed with an injection volume of $10 \mu \mathrm{L}$. The total chromatographic run time was $15 \mathrm{~min}$. The elution was performed with varied gradient as follows: 0-1.0 min 5\% B, 1.0-5.0 min 5-50\% B, 5.0-6.5 min $50 \%$ B, 6.5-7.5 min $50-65 \%$ B, $7.5-8.5 \min 65 \%$ B, 8.5-9.5 min $65-100 \% \mathrm{~B}, 9.5-12.0 \mathrm{~min} 100 \% \mathrm{~B}$, and 12.1-15.0 min 5\% B for equilibrium. After the injection of each sample, the needle was rinsed alternately with methanol and water. A two-position diverter valve was used and settings were as follows: detector over $0-8.5 \mathrm{~min}$, waste over $8.5-15.0 \mathrm{~min}$. The MS ion source was set as APCI in positive mode, under the following conditions: temperature, $400{ }^{\circ} \mathrm{C}$; curtain gas pressure, 25 psi; collision gas pressure of medium level, ion source gas, $50 \mathrm{psi}$; and nebulizer current, $5 \mu \mathrm{A}$. The selectivity for precursor ion (Q1) and product ions (Q3) was set to $0.7 \mathrm{~m} / \mathrm{z}$ (FWHM).

\subsection{Robustness}

To examine the robustness of the proposed method, the effect of deliberation variations was investigated by following parameters such as mobile phase additive $(0.1-0.2 \%$ formic acid), organic components of mobile phase (20-40\% acetonitrile in methanol) and flow rate of mobile phase $(0.3-0.6 \mathrm{~mL} / \mathrm{min})$.

\subsection{Preparation of standard solutions}

Stock solutions of 12 nitrosamines and 5 internal standards (IS) were prepared in methanol at $1000 \mu \mathrm{g} / \mathrm{mL}$ and $50 \mu \mathrm{g} / \mathrm{mL}$, respectively. The internal standard solution was prepared by diluting the internal standard stock solution with methanol to a concentration of $400 \mathrm{ng} / \mathrm{mL}$ prior to use. A series of working standard solutions for calibration curve were prepared at concentrations of 2.5, 5.0, 10.0, 20.0, 25.0 and $50.0 \mathrm{ng} / \mathrm{mL}$ with $20 \mathrm{ng} / \mathrm{mL}$ of the internal standard. All the stock and working solutions were stored at $-30{ }^{\circ} \mathrm{C}$ and acclimated to room temperature prior to use.

\subsection{Sample preparation}

Transfer $250 \mathrm{mg}$ of sartan API (or ground tablet powder of final product) to a $15 \mathrm{~mL}$ centrifuge tube. Add $250 \mu \mathrm{L}$ of the internal standard solution (400 ng/mL) as well as $250 \mu \mathrm{L}$ of methanol (for validation, $250 \mu \mathrm{l}$ of nitrosamine standard solution at concentration of interest was added) to the tube, and sonicated for $5 \mathrm{~min}$ to make an extraction solution. Add $4.5 \mathrm{~mL}$ of DI water to the extraction solution above and sonicate for $5 \mathrm{~min}$. Centrifuge the sample solution at $3000 \times \mathrm{g}$ for $5 \mathrm{~min}$, filter the solution through a $0.22 \mu \mathrm{m}$ PVDF filter, and then collect the filtrate, which was used as the sample solution.

\subsection{Method validation}

\subsubsection{Linearity and sensitivity}

The linearity was assessed by analyzing standard solutions of 12 nitrosamines $(n=3)$ at 6 concentrations ranging from 2.5 to $50.0 \mathrm{ng} / \mathrm{mL}$ by plotting the peak area ratio of standard/internal standard versus the concentration of standard using the leastsquares method estimated by logistic regression. The linearity is acceptable when the correlation coefficient $r$ was higher than 0.995 . The sensitivity of the method was evaluated using the limit of detection (LOD) and limit of quantification (LOQ) according to $\mathrm{ICH}$ validation of analytical procedures [27]. The LOD is the lowest concentration of analyte that can be detected with the estimated signal-tonoise $(\mathrm{S} / \mathrm{N})$ ratio of 3 . The LOQ is the lowest concentration of analyte that can be quantified with the suitable precision and accuracy using an estimated S/N ratio of 10.

\subsubsection{Accuracy and precision}

Before assessing the accuracy (expressed as recovery, \%), all sartan matrices were examined to be absent of nitrosamines and so that the interference to standards could be avoided. The accuracy was evaluated by introducing quality control (QC) for nitrosamines in sartan materices [27]. The procedure was in reference of $\mathrm{ICH}$ and followed the criteria for QC in chemical analysis set up by TFDA (for 


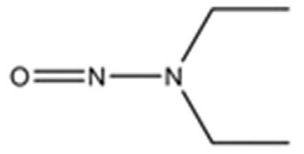

$N$-nitrosodiethylamine (NDEA)<smiles>CN(C)N=O</smiles>

$N$-nitrosodimethylamine (NDMA)<smiles>CCN(C)N=O</smiles>

$N$-nitrosodimethylethylamine (NMEA)<smiles>O=NN(CCO)CCO</smiles>

$N$-nitrosodiethanolamine (NDELA)<smiles>CCCN(CCC)N=O</smiles>

$N$-nitrosodipropylamine (NDPA)<smiles>O=NN1CCOCC1</smiles>

$N$-nitrosomorpholine (NMOR)<smiles>CC(C)N(N=O)C(C)C</smiles>

$N$-nitrosodiisopropylamine (NDiPA)<smiles>CCN(N=O)C(C)C</smiles>

$N$-nitrosoethylpropylamine (NEIPA)<smiles>O=NN1CCCCC1</smiles>

$N$-nitrosopiperidine (NPIP)<smiles>CC(O)CN(CC(C)O)N=O</smiles>

$\mathrm{N}$-nitrosodiisopropanolamine (NDiPLA)<smiles>CN(CCCC(=O)O)N=O</smiles>

$N$-nitroso- $N$-methyl-4-aminobutyric acid (NMBA)

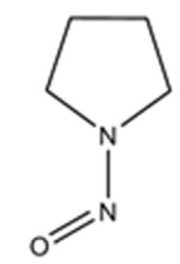

$N$-nitrosopyrrolidine (NPYP)

Fig. 1. Chemical structures of 12 nitrosamines analyzed in this study.<smiles>CCOc1nc2cccc(C(=O)OC(C)OC(=O)OC3CCCCC3)c2n1Cc1ccc(-c2ccccc2-c2nn[nH]n2)cc1</smiles>

Candesartan cilexetil<smiles>CCCCC1=NC2(CCCC2)C(=O)N1Cc1ccc(-c2ccccc2-c2nn[nH]n2)cc1</smiles>

Irbesartan<smiles>CCCCc1nc(Cl)c(CO)n1Cc1ccc(-c2ccccc2-c2nn[nH]n2)cc1</smiles>

Losartan<smiles>CCCc1nc(C(C)(C)O)c(C(=O)OCc2oc(=O)oc2C)n1Cc1ccc(-c2ccccc2-c2nn[nH]n2)cc1</smiles>

Olmesartan medoxomil<smiles>CCCCC(=O)N(Cc1ccc(-c2ccccc2-c2nn[nH]n2)cc1)C(C(=O)O)C(C)C</smiles>

Valsartan

Fig. 2. Chemical structures of 5 sartans analyzed in this study. 
Table 1. MRM parameters of 12 nitrosamines and 5 internal standards.

\begin{tabular}{|c|c|c|c|c|}
\hline \multirow[t]{2}{*}{ Analyte } & \multirow[t]{2}{*}{$\mathrm{RT}(\min )$} & MRM transitions & \multirow[t]{2}{*}{$\mathrm{DP}(\mathrm{V})$} & \multirow[t]{2}{*}{$\mathrm{CE}(\mathrm{eV})$} \\
\hline & & $(m / z)$ & & \\
\hline \multirow[t]{2}{*}{ NDELA } & \multirow[t]{2}{*}{1.88} & $135>74^{\mathrm{a}}$ & \multirow[t]{2}{*}{29} & 17 \\
\hline & & $135>104^{b}$ & & 9 \\
\hline \multirow[t]{2}{*}{ NDMA } & \multirow[t]{2}{*}{2.7} & $75>58^{a}$ & \multirow[t]{2}{*}{28} & 15 \\
\hline & & $75>43^{b}$ & & 21 \\
\hline \multirow[t]{2}{*}{ NMOR } & \multirow[t]{2}{*}{3.5} & $117>87^{\mathrm{a}}$ & \multirow[t]{2}{*}{38} & 17 \\
\hline & & $117>86^{\mathrm{b}}$ & & 20 \\
\hline \multirow[t]{2}{*}{ NDiPLA } & \multirow[t]{2}{*}{3.75} & $163>88^{\mathrm{a}}$ & \multirow[t]{2}{*}{44} & 17 \\
\hline & & $163>70^{b}$ & & 28 \\
\hline \multirow[t]{2}{*}{ NMBA } & \multirow[t]{2}{*}{3.84} & $147>117^{\mathrm{a}}$ & \multirow[t]{2}{*}{10} & 8 \\
\hline & & $147>87^{\mathrm{b}}$ & & 16 \\
\hline \multirow[t]{2}{*}{ NMEA } & \multirow[t]{2}{*}{3.95} & $89>61^{a}$ & \multirow[t]{2}{*}{7} & 16 \\
\hline & & $89>29^{b}$ & & 27 \\
\hline \multirow[t]{2}{*}{ NPYR } & \multirow[t]{2}{*}{4.0} & $101>55^{\mathrm{a}}$ & \multirow[t]{2}{*}{58} & 22 \\
\hline & & $101>41^{b}$ & & 37 \\
\hline \multirow[t]{2}{*}{ NDEA } & \multirow[t]{2}{*}{5.3} & $103>75^{\mathrm{a}}$ & \multirow[t]{2}{*}{25} & 13 \\
\hline & & $103>47^{b}$ & & 29 \\
\hline \multirow[t]{2}{*}{ NPIP } & \multirow[t]{2}{*}{5.62} & $115>69^{\mathrm{a}}$ & \multirow[t]{2}{*}{42} & 21 \\
\hline & & $115>41^{b}$ & & 33 \\
\hline NEIPA & 6.27 & $117>75^{a}$ & 16 & 14 \\
\hline & & $117>47^{b}$ & & 22 \\
\hline NDiPA & 7.46 & $131>89^{a}$ & 50 & 13 \\
\hline & & $131>43^{b}$ & & 22 \\
\hline NDPA & 8.15 & $131>89^{a}$ & 59 & 14 \\
\hline & & $131>43^{b}$ & & 21 \\
\hline NDELA-d $_{8}$ & 1.87 & $143>111^{\mathrm{a}}$ & 23 & 8 \\
\hline NDMA-d ${ }_{6}$ & 2.65 & $81>46^{\mathrm{a}}$ & 106 & 25 \\
\hline NMBA-d 3 & 3.82 & $150>120^{\mathrm{a}}$ & 36 & 9 \\
\hline NDEA-d & 5.25 & $107>77^{\mathrm{a}}$ & 48 & 16 \\
\hline NDPA-d $d_{14}$ & 7.99 & $145>50^{\mathrm{a}}$ & 130 & 46 \\
\hline
\end{tabular}

MRM, multiple reaction monitoring; RT: retention time.

${ }^{a}$ Quantifier.

b Qualifier; CE: collision energy; DP: declustering potential.

$1.0-10.0 \mathrm{ng} / \mathrm{mL}$, recovery $60-125 \%$, RSD $30 \%$; for $10.0-100.0 \mathrm{ng} / \mathrm{mL}$, recovery $70-120 \%$, RSD $20 \%$ ). The intra-day and inter-day accuracy (\%) and precision (RSD in \%) of the assay were assessed at 3 concentration levels from low to high within the calibration curve $(5.0,25.0$, and $50.0 \mathrm{ng} / \mathrm{mL})$ in 3 replicates. The accuracy was assessed by comparing the estimated concentration of analyte in matrix (A) with that of standard solution (B), whereas the ratio was calculated as following formula: $A / B \times 100 \%$. The assessment was performed as follows: for intraday, 3 samples for each concentration, and 1 replicate for each sample, $\mathrm{n}=3$; for inter-day, 3 samples for each concentration, 1 replicate for each sample, for 3 consecutive days, $\mathrm{n}=9$.

\section{Results and discussion}

\subsection{Optimization of chromatographic conditions}

To optimize the chromatographic conditions, the APCI was selected as the ionization source for determination of nitrosamines in this study; nevertheless, ESI can also be applied as an alternative when the target is not vaporized by APCI [27]. In the literature, the advantages of APCI such better performance in selecting ions and less susceptible to matrices for determination of nitrosamines have been reported $[22,28]$. Preliminary tests were carried out to assess the adaptability of ionization sources in detecting nitrosamines. Accordingly, APCI showed higher signals for all nitrosamines and thus selected as the ionization source in this study. The MRM chromatograms of 12 nitrosamines with APCI are presented in Fig. 3. The MRM parameters with APCI including are summarized in Table 1. Q1 and Q3 for all analytes are within $0.7 \mathrm{~m} / z$ FWHM. Defects for some chromatograms were observed during analysis. A doublet peak of NDiPLA chromatogram with same MRM transitions appeared which may indicate the separation of racemic mixture or zwitterions of NDiPLA analyzing on Xselect $^{\circledR}$ HSS T3 column. The peak shoulder observed in the NMEA and NMBA chromatograms was attributed to $\mathrm{pH}$ adaptation of mobile phase. All the doublet peak and peak shoulder mentioned above were adopted to reduce the deviation in quantification and validation.

\subsection{Robustness}

To evaluate the effect of mobile phase on separation, quantification and peak width of analytes, parameters such as additive $(0.1-0.2 \%$ formic acid), organic component $(20-40 \%$ acetonitrile in methanol) and flow rate $(0.3-0.6 \mathrm{~mL} / \mathrm{min})$ were investigated. The results indicated that the conditions of mobile phase had only slight influence on peak width (less than $0.1 \mathrm{~min}$ for all analytes) which supports the robustness of the proposed method.

\subsection{Method validation}

\subsubsection{Linearity and sensitivity}

The linearity of 12 nitrosamines was obtained up to $50.0 \mathrm{ng} / \mathrm{mL}$ and the data are presented in Table 2 . The values of correlation coefficient $r$ were higher than 0.995 for all analytes which indicated that the most IS applied in qualification were highly recommendable for the targets analyzed in this study. The LOD and LOQ determined for all analytes in sartan APIs and final products were $20.0 \mathrm{ng} /$ $\mathrm{g}$ and $50.0 \mathrm{ng} / \mathrm{g}$, respectively. In the literatures, methods have been developed for determination of nitrosamines in sartans. Schmidtsdorff and Schmidt developed a method for determination of 9 nitrosamines (NDBA, NDEA, NDMA, NDPA, NDPhA, NMEA, NMOR, NPIP and NPYR) using 
supercritical fluid chromatography which the LODs ranged from 50 to $140 \mathrm{ng} / \mathrm{g}$ in valsartan and 20-460 ng/g in losartan [29]; el-Atma and Gutsche reported a LC-MS/MS method for determination of 2 nitrosamines which the LODs for NDEA and NDMA were 20 and $70 \mathrm{ng} / \mathrm{g}$, respectively, while the LOQs for NDEA and NDMA were 40 and $100 \mathrm{ng} / \mathrm{g}$, respectively [30]. Compared to the published methods, this study demonstrated a variety of targets and sensitivity of detection for determination of nitrosamines in sartans.

\subsubsection{Accuracy and precision}

The intra-day accuracy of nitrosamines for sartan APIs was $81.4-117.0 \%$, while the precision (RSD) located in the range of $0.7-9.8 \%$; for sartan final products, the value was $82.6-118.4 \%$, while the precision located in the range of $0.3-13.1 \%$. The inter-day accuracy of nitrosamines for sartan APIs was $81.7-117.5 \%$, while the precision located in the range of $1.2-10.5 \%$; for sartan final products, the value was $82.9-118.0 \%$, while the precision located in the range of $0.8-12.8 \%$. The assessment of

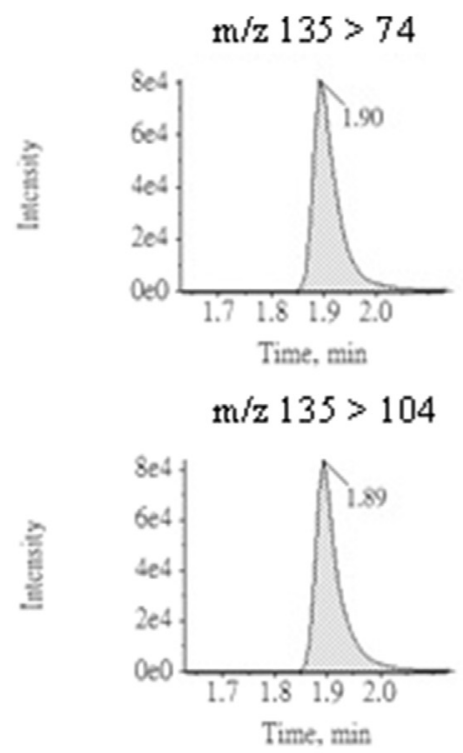

(A) NDELA

$$
\mathrm{m} / \mathrm{z} 163>88
$$

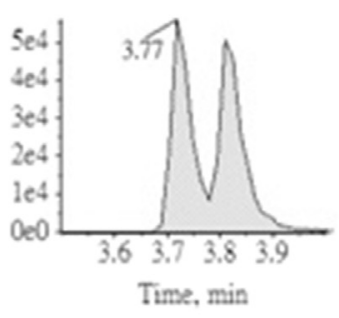

$\mathrm{m} / \mathrm{z} 163>70$

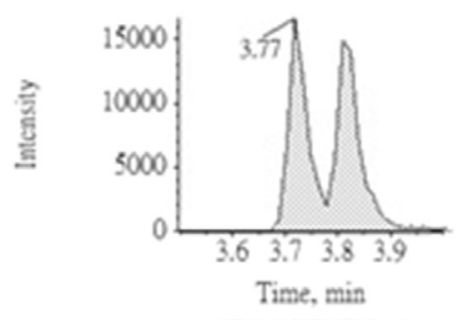

(D) NDiPLA $\mathrm{m} / \mathrm{z} 75>58$

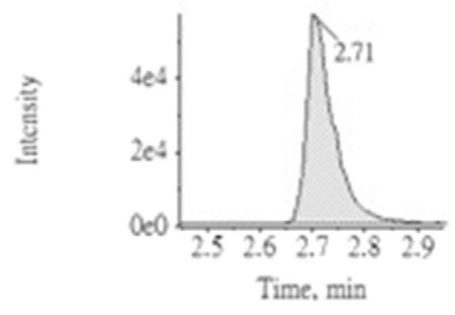

$\mathrm{m} / \mathrm{z} 75>43$

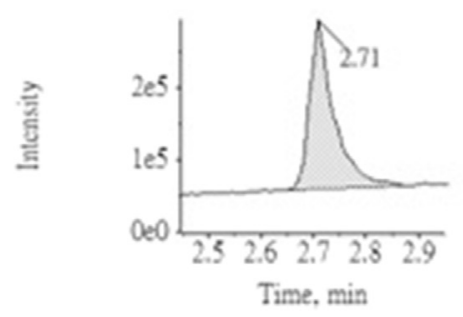

(B) NDMA

$\mathrm{m} / \mathrm{z} 147>117$

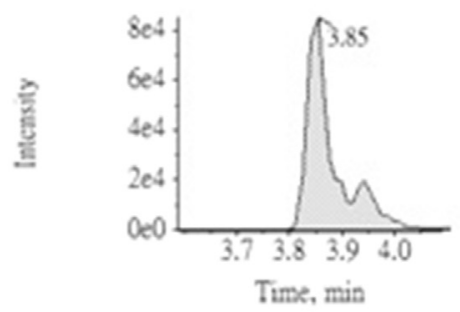

$\mathrm{m} / \mathrm{z} 147>87$

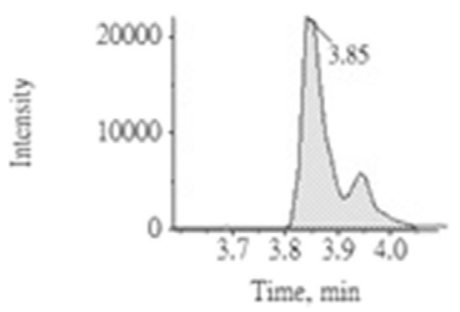

(E) NMBA $\mathrm{m} / \mathrm{z} 117>87$
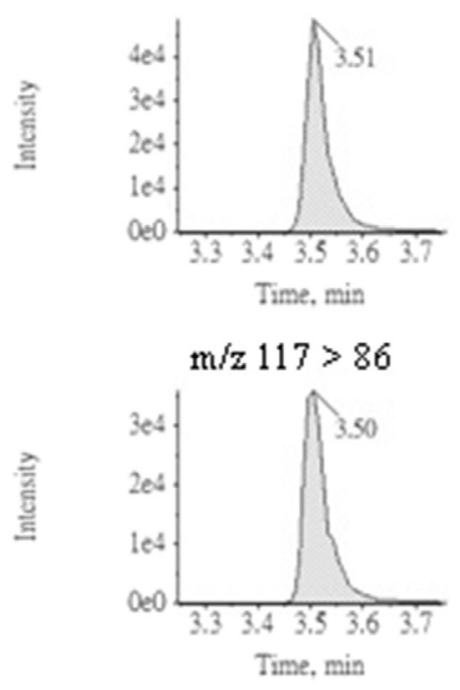

(C) NMOR
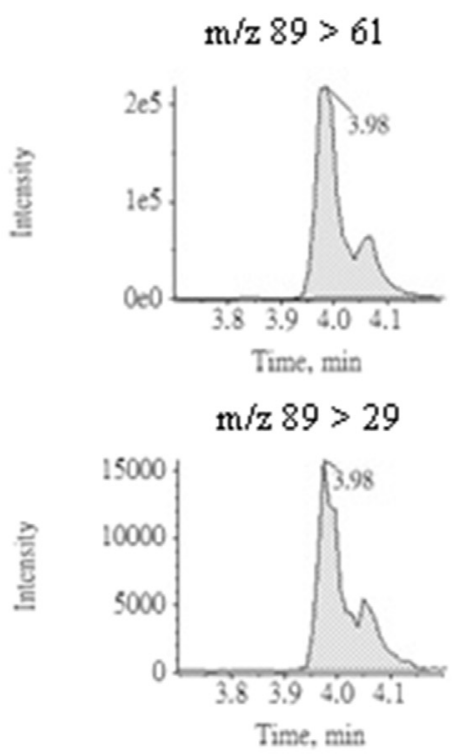

(F) NMEA

Fig. 3. MRM chromatograms applying APCI ionization source for 12 nitrosamines and 5 internal standards. 


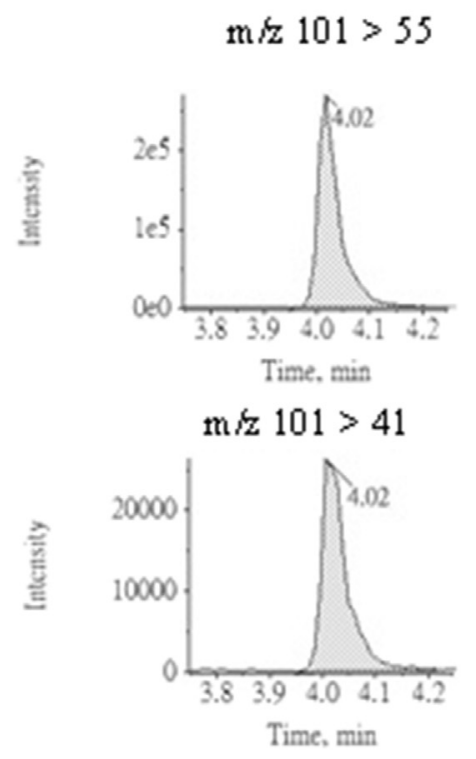

(G) NPYR
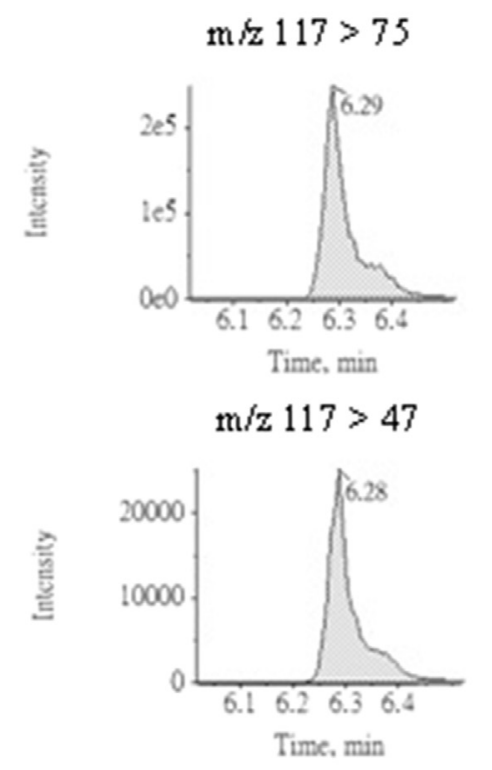

(J) NEIPA
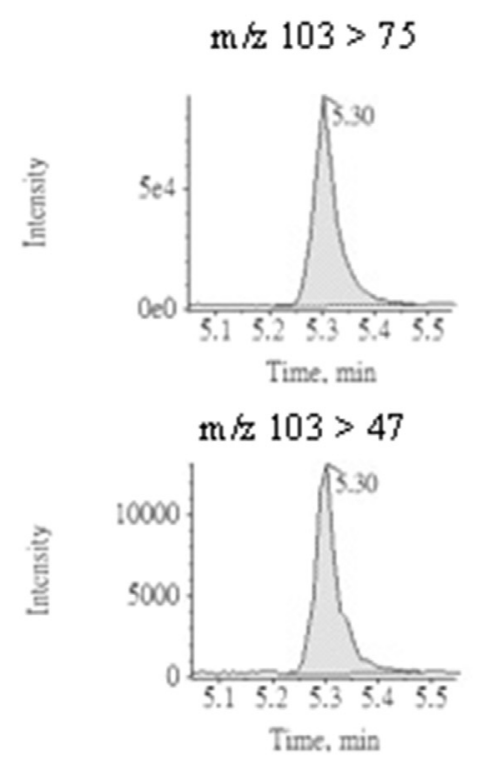

(H) NDEA

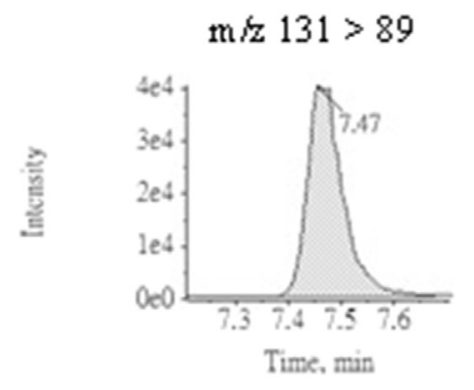

$\mathrm{m} / \mathrm{z} 131>43$

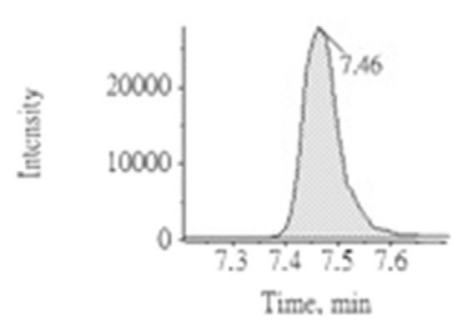

(K) NDiPA
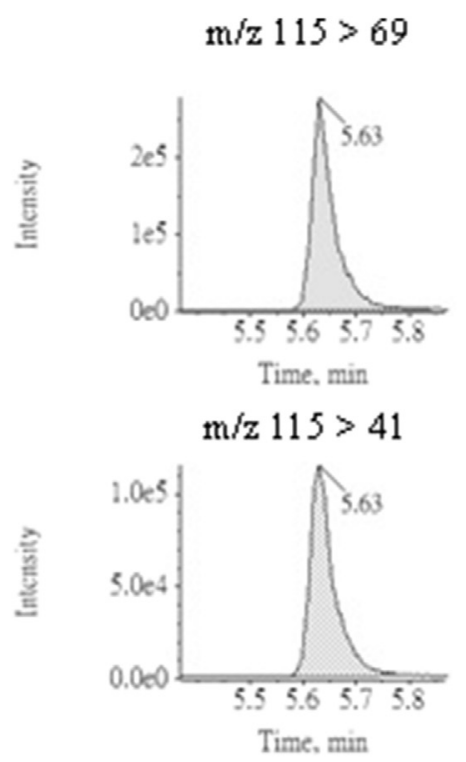

(I) NPIP

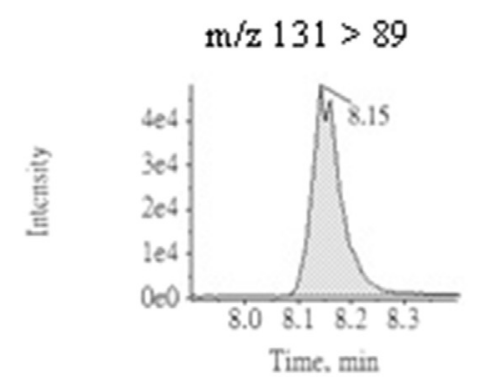

$m / z \quad 131>43$

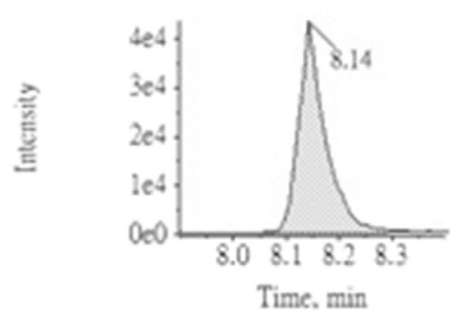

(L) NDPA

Fig. 3. (continued). 


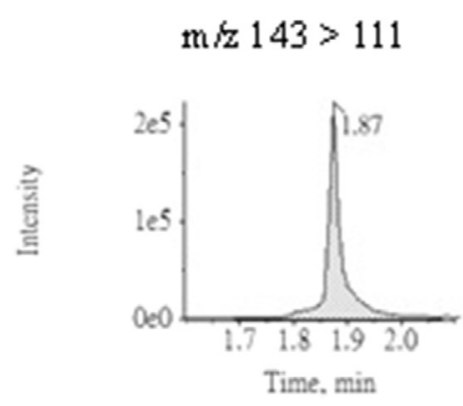

(M) NDELA-do

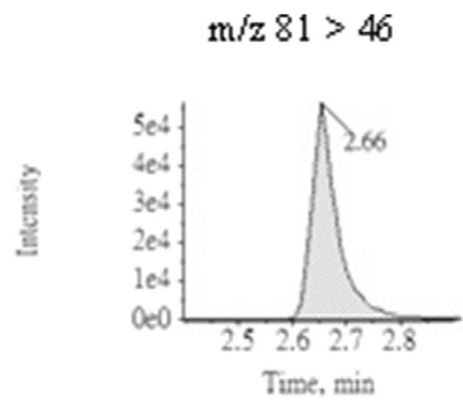

(N) NDMA-d6

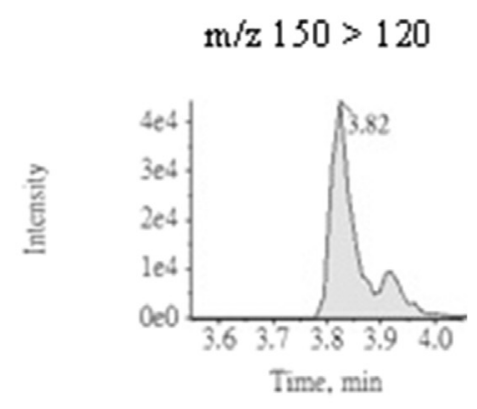

(O) NMBA-d 3 $\mathrm{m} / \mathrm{z} 107>77$

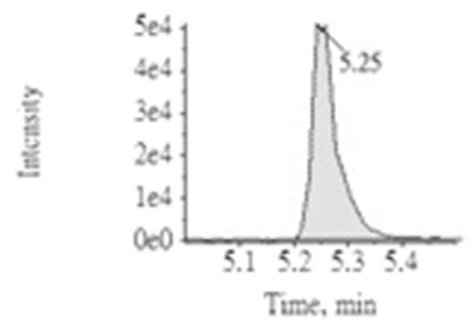

(P) NDEA-d4

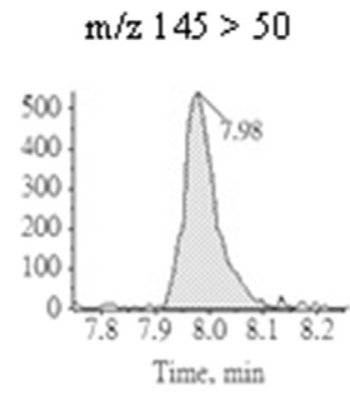

(Q) NDPA-d 14

Fig. 3. (continued).

accuracy and precision met the criteria (see section 2.6.2) for most nitrosamines within 5 sartan matrices, except for NDiPA and NEIPA within irbesartan matrix. The intra-day accuracy of NDiPA for irbesartan API was 139.1-160.3\%, where it was 97.3-124.1\% for irbesartan final products; the interday accuracy of NDiPA for irbesartan API was $140.3-176.9 \%$, where it was $113.1-126.0 \%$ for irbesartan final products. The intra-day accuracy of NEIPA for irbesartan API was 64.5-70.3\%, where it was $47.5-49.3 \%$ for irbesartan final products; the inter-day accuracy of NEIPA for irbesartan API was $65.9-71.2 \%$, where it was $46.3-48.9 \%$ for irbesartan final products. The result of accuracy and precision for NDiPA (NEIPA) within irbesartan matrix indicated the chromatographic intensity was enhanced (suppressed) owing to the matrix interference of irbesartan, i.e. the intensity of corresponding internal standards NDPA- $d_{14}\left(N D E A-d_{4}\right)$ were enhanced (suppressed) and resulted in the mis-estimation in quantification. To improve the disadvantage, the corresponding internal standards for NDiPA and NEIPA could be replaced by alternative isotropic nitrosamines to receive a better performance in the assessment of accuracy and precision.
Table 2. Linearity data of 12 nitrosamines.

\begin{tabular}{lllll}
\hline Analyte & $\begin{array}{l}\text { Linear } \\
\text { range }(\mathrm{ng} / \mathrm{mL})\end{array}$ & Slope & Intercept & $\begin{array}{l}\text { Correlation } \\
\text { coefficient }(\mathrm{r})\end{array}$ \\
\hline NDELA & $2.5-50.0$ & 0.23769 & 0.00298 & 0.9989 \\
NDMA & $2.5-50.0$ & 0.40608 & 0.00448 & 0.9988 \\
NMOR & $2.5-50.0$ & 0.34094 & -0.00193 & 0.9993 \\
NDiPLA & $2.5-50.0$ & 0.75543 & -0.00435 & 0.9995 \\
NMBA & $2.5-50.0$ & 0.82797 & -0.00702 & 0.9977 \\
NMEA & $2.5-50.0$ & 2.18029 & 0.01566 & 0.9994 \\
NPYR & $2.5-50.0$ & 2.23857 & 0.02065 & 0.9992 \\
NDEA & $2.5-50.0$ & 0.58442 & $-2.22599 \mathrm{e}-4$ & 0.9994 \\
NPIP & $2.5-50.0$ & 2.06747 & -0.04224 & 0.9983 \\
NEIPA & $2.5-50.0$ & 2.11105 & 0.00859 & 0.9992 \\
NDiPA & $2.5-50.0$ & 27.90931 & 0.51163 & 0.9994 \\
NDPA & $2.5-50.0$ & 31.94901 & 0.85289 & 0.9996 \\
\hline
\end{tabular}

\subsection{Analysis of authentic samples}

557 samples from 5 different sartans acquired from local public health bureaus were analyzed and the result was shown in Fig. 4. A total of 98 positive samples were detected from 557 authentic samples which 3 sartan medicines, including irbesartan, losartan, and valsartan were detected positive of nitrosamines. Among those samples, valsartan had the highest detection rate of nitrosamine-positive 


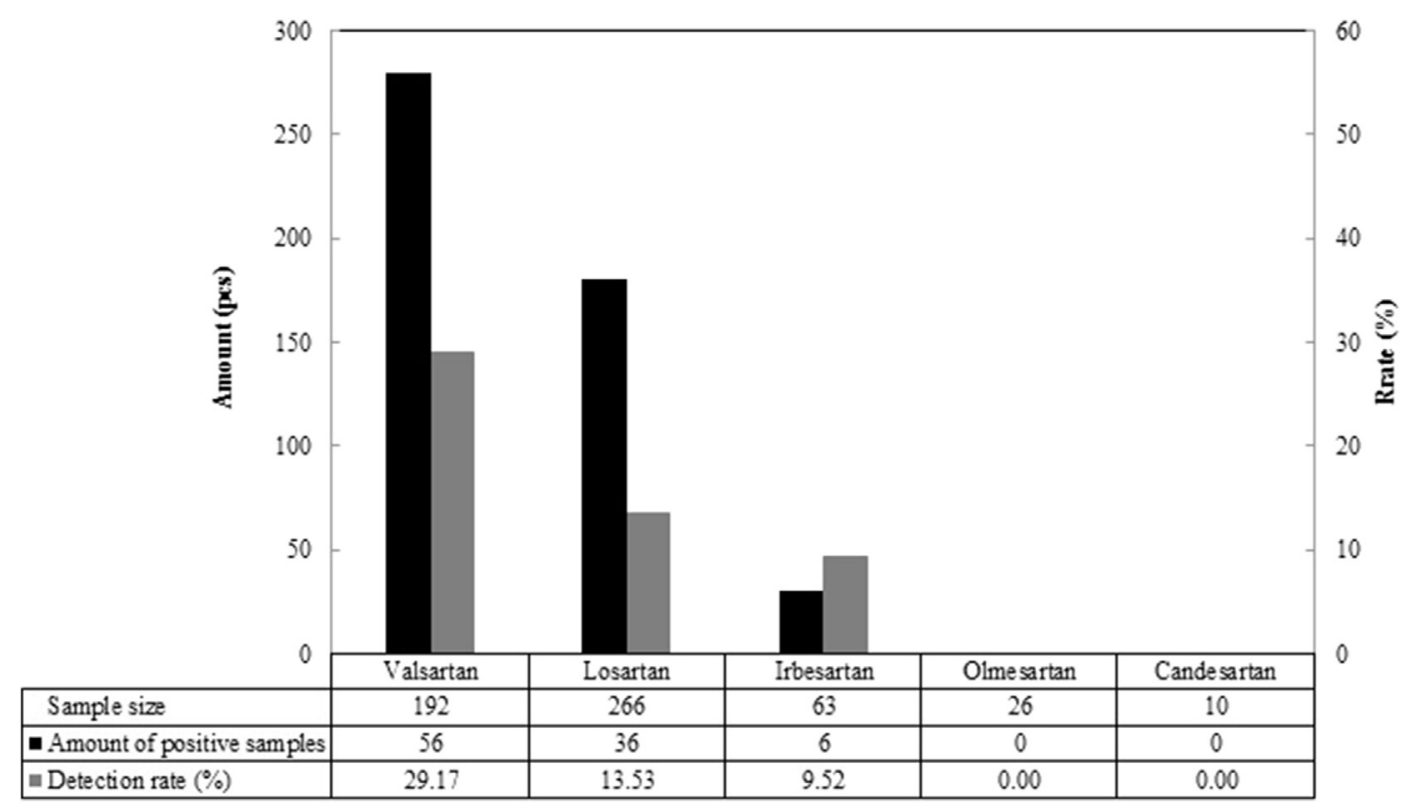

Fig. 4. Amount and detection rate of nitrosamine-positive samples from authentic samples.

Table 3. Amount and content of corresponding nitrosamine detected in positive samples.

\begin{tabular}{|c|c|c|c|c|c|c|c|c|c|c|}
\hline \multirow[t]{2}{*}{ Item } & \multicolumn{2}{|l|}{ NDMA } & \multicolumn{2}{|l|}{ NDEA } & \multicolumn{2}{|l|}{ NMBA } & \multicolumn{2}{|l|}{ NMOR } & \multicolumn{2}{|l|}{ NPIP } \\
\hline & $\begin{array}{l}\text { Amount }^{a} \\
\text { (pcs) }\end{array}$ & $\begin{array}{l}\text { Content } \\
(\mu \mathrm{g} / \mathrm{g})\end{array}$ & $\begin{array}{l}\text { Amount } \\
(\mathrm{pcs})\end{array}$ & $\begin{array}{l}\text { Content } \\
(\mu \mathrm{g} / \mathrm{g})\end{array}$ & $\begin{array}{l}\text { Amount } \\
(\mathrm{pcs})\end{array}$ & $\begin{array}{l}\text { Content } \\
(\mu \mathrm{g} / \mathrm{g})\end{array}$ & $\begin{array}{l}\text { Amount } \\
\text { (pcs) }\end{array}$ & $\begin{array}{l}\text { Content } \\
(\mu \mathrm{g} / \mathrm{g})\end{array}$ & $\begin{array}{l}\text { Amount } \\
\text { (pcs) }\end{array}$ & $\begin{array}{l}\text { Content } \\
(\mu \mathrm{g} / \mathrm{g})\end{array}$ \\
\hline Valsartan & 53 & $0.10-137.60$ & 11 & $0.07-6.90$ & 1 & 0.14 & 2 & 0.16 & 2 & 0.12 \\
\hline Losartan & 0 & $\mathrm{ND}$ & 4 & $0.08-0.23$ & 32 & $0.22-27.40$ & 0 & ND & 0 & ND \\
\hline Irbesartan & 0 & ND & 5 & $0.11-0.12$ & 0 & ND & 0 & ND & 0 & ND \\
\hline
\end{tabular}

${ }^{\mathrm{a}}$ Amount of contaminated samples sorted according to corresponding nitrosamine.

samples $(29.17 \%)$, i.e. 56 out of 192 samples were detected positive, followed by losartan (36/266, $13.53 \%)$ and irbesartan $(6 / 63,9.52 \%)$. The result of detection was further interpreted to sort the types of nitrosamines, and demonstrated in Table 3. 5 nitrosamines, including NDEA, NDMA, NMBA, NMOR and NPIP, were detected in the 3 sartan medicines mentioned above. For valsartan, most of the positive samples (53/56) were detected having NDMA, which the content attained to an enormous level of $137.6 \mu \mathrm{g} / \mathrm{g}$ and indicated NDMA as the main contaminant produced as by-product in the modification of manufacturing process of valsartan. As to losartan, the majority of the positive samples (32/36) were detected having NMBA at the content level of $27.40 \mu \mathrm{g} / \mathrm{g}$ which posed that NMBA was the main contaminant produced as by-product in the modification of manufacturing process of losartan. For a better understanding, all positive samples were employed to examine if it is possible that more than 2 contaminants were detected in sartan medicines. Not surprisingly, multiple nitrosamine contents were found. In the positive samples of valsartan medicines, 8 samples possessed 2 contaminants NDMA and NDEA; 2 samples possessed 3 contaminants NDEA, NMOR and NPIP; 1 sample possessed 3 contaminants NDEA, NDMA and NMBA. Echo to the description in introduction, as long the conditions were sufficient, various nitrosamines would be produced which followed that the modification of sartan APIs manufacturing process intensively affected the quality of pharmaceuticals and led to the cross-border incident of medication safety.

\section{Conclusion}

In this study, a multi-analyte LC-MS/MS method was successfully developed for screening and determination of 12 nitrosamines in sartan medicines. The proposed method was validated and provided satisfactory result of validation for target nitrosamines in most APIs and final products which demonstrated a good performance and specificity for the method in screening and qualification of nitrosamines. 


\section{Acknowledgments}

We gratefully acknowledge the financial support from Food and Drug Administration, Ministry of Health and Welfare, Taiwan.

\section{References}

[1] Muszalska I, Sobczak A, Dolhan A, Jelinska A. Analysis of sartan: a review. J Pharm Sci 2014;103:2-28.

[2] Siddiqui N, Husain A, Chaudhry L, Alam MS, Mitra M, Bhasin PS. Pharmacological and pharmaceutical profile of valsartan: a review. J Appl Pharmaceut Sci 2011;1:12-9.

[3] Al-Majed AA, Assiri E, Khalil NY, Abdel-Aziz HA. Chapter three-losartan: comprehensive profile. Profiles Drug Subst Excipients Relat Methodol 2015;40:159-94.

[4] Burnier N, Brunner HR. Angiotensin II receptor antagonists. Lancet 2000;355:637-45.

[5] Ardiana F, Suciati Indrayanto G. Profiles of drug substances, excipients and related methodology. Chapter seven-Valsar$\tan 2015 ; 40: 431-93$.

[6] Srinivasan V, Sivaramakrishnan H, Karthikeyan B. Detection, isolation and characterization of principle synthetic route indicative impurity in telmisartan. Arab J Chem 2016;9: S1516-22.

[7] Pandey KA, Rapolu R, Raju CK, Sasalamari G, Goud KS, Awasthi A, et al. The novel acid degradation products of losartan: isolation and characterization using Q-TOF, 2DNMR and FTIR. J Pharmaceut Biomed Anal 2016;120:65-71.

[8] EMA 641563. Valsartan: review of impurities extended to other sartan medicines. EMA/641563/2018. London: European Medicines Agency; 2018.

[9] EMA 485921. Update on review of valsartan medicines following detection of impurity in active substance. EMA/ 485921/2018. London: European Medicines Agency; 2018.

[10] EMA 643116. EMA review of impurities in sartan medicines. EMA/643116/2018. London: European Medicines Agency; 2018.

[11] Cohen JB, Bachman JD. Measurement of environmental nitrosamines. IARC Sci Publ 1978;19:357-72.

[12] Mitch WA, Sharp JOR, Trussell R, Valentine RL, AlvarezCohen L, Sedlak DL. N-Nitrosodimethylamine (NDMA) as a drinking water contaminant: a review. Environ Eng Sci 2003; 20:389-404.

[13] Mirvish SS. Formation of $N$-nitroso compounds: chemistry, kinetics and in vivo occurrence. Toxicol Appl Pharmacol 1975;31:325-51.

[14] Wainright $T$. The chemistry of nitrosamine formation: relevance to malting and brewing. J Inst Brew 1986;92:49-64.

[15] Mitch WA, Sedlak DL. Formation of N-nitrosodimethylamine (NDMA) from dimethylamine during chlorination. Environ Sci Technol 2002;36:588-95.

[16] Masada S, Tsuji G, Arai R, Uchiyama N, Demizu Y, Tsutsumi T, et al. Rapid and efficient high-performance liquid chromatography analysis of $N$-nitrosodimethylamine impurity in valsartan drug substance and its products. Sci Rep 2019;9:11852.

[17] WHO. N-nitrosodimethylamine. Concise international chemical assessment document 38. Geneva: World Health Organization; 2002.
[18] Wang W, Hu J, Yu J, Yang M. Determination of N-nitrosodimethylamine in drinking water by UPLC-MS/MS J Environ Sci 2010;22:1508-12.

[19] Selin NE. Environmental guidelines and regulations for nitrosamines: a policy summary, final report revision 2. Engineering systems and atmospheric chemistry engineering systems division and department of earth, atmospheric and planetary Sciences, Massachusetts Institute of Technology.

[20] U.S. Environmental Protection Agency (EPA). Second unregulated contaminant monitoring rule, screening survey (list 2 contaminants). https://www.epa.gov/dwucmr/secondunregulated-contaminant-monitoring-rule\#assess.

[21] FDA updates and press announcements on angiotensin II receptor blocker (ARB) recalls (valsartan, losartan, and irbesartan): interim limits for NDMA, NDEA, and NMBA in angiotensin II receptor blockers (ARBs). https://www.fda. gov/Drugs/DrugSafety/ucm613916.htm.

[22] Ripollés C, Pitarch E, Sancho JV, López FJ, Hernández F. Determination of eight nitrosamines in water at the $\mathrm{ng} \mathrm{L}^{-1}$ levels by liquid chromatography coupled to atmospheric pressure chemical ionization tandem mass spectrometry. Anal Chim Acta 2011;702:62-71.

[23] Jurado-Sanchez B, Ballesteros E, Gallego M. Screening of Nnitrosamines in tap and swimming pool waters using fast gas chromatography. J Separ Sci 2010;33:610-6.

[24] Parr MK, Joseph JF. NDMA impurity in valsartan and other pharmaceutical products: analytical methods for the determination of $N$-nitrosamines. J Pharmaceut Biomed Anal 2019;164:536-49.

[25] Scherf-Clavel O, Kinzig M, Besa A, Schreiber A, Bidmon C, Abdel-Tawab M, et al. The contamination of valsartan and other sartans, Part 2: untargeted screening reveals contamination with amides additionally to known nitrosamine impurities. J Pharmaceut Biomed Anal 2019;172:278-84.

[26] Li Z, Wang J, Chen X, Hu Sg, Gong T, Xian Q. A novel molecularly imprinted polymer-solid phase extraction method coupled with high performance liquid chromatography tandem mass spectrometry for the determination of nitrosamines in water and beverage samples. Food Chem 2019;164:536-49.

[27] ICH. Q2 (R1) validation of analytical procedures: text and methodology. In: International conference on harmonisation of technical requirements for registration of pharmaceuticals for human use; 2005. ICH home page, http://www.ich.org. [Accessed 1 February 2018].

[28] Lee JH, Lee SU, Oh JE. Analysis of nine nitrosamines in water by combining automated solid-phase extraction with high-performance liquid chromatography-atmospheric pressure chemical ionisation tandem mass spectrometry. Int J Environ Anal Chem 2013;12:1261-73.

[29] Schmidtsdorff S, Schmidt AH. Simultaneous detection of nitrosamines and other sartan-related impurities in active pharmaceutical ingredients by supercritical fluid chromatography. J Pharmaceut Biomed Anal 2019;174: $151-60$.

[30] el-Atma O, Gutsche B. Test method for the determination of NDMA and NDEA by LC-MS/MS in sartan containing film coated tablets. Chemisches Und Veterinäruntersuchungsamt Karlsruhe 2018:1-7. 